\title{
High meiofauna standing stock in hadal trenches and linkage to food availability
}

MAURICIO SHIMABUKURO ${ }^{1,2}$, RONNIE N GLUD ${ }^{1}$, DANIEL LEDUC ${ }^{3}$, FRANK WENZHÖFER ${ }^{1,4,5}$, ASHLEY ROWDEN $^{3}$ AND DANIELA ZEPPILLI ${ }^{2}$

${ }^{1}$ University of Southern Denmark

${ }^{2}$ Institut Français de Recherche pour l'Exploitation de la Mer

${ }^{3}$ National Institute of Water and Atmospheric Research

${ }^{4}$ Max Planck Institute for Marine Microbiology

${ }^{5}$ Alfred Wegener Institute Helmholtz Centre for Polar and Marine Research

Presenting Author: mshima84@gmail.com

The Atacama Trench is underlying one of the globally most productive open-ocean regions and limited published data suggest that the seafloor of the trench is a hotspot for meiofauna. We tested this hypothesis by quantifying meiofauna standing stocks (density and biomass) at six trench axis sites, two adjacent abyssal sites and one bathyal site. For all sites, the vertical distribution of meiofauna standing stock was highest in the top centimeter of sediment and rapidly decreased in subsurface layers. This pattern was clearly correlated to the volume specific oxygen consumption rates may indicating that intensified activity in sediment surface increase meiofauna standing stock. Indeed, the depth integrated meiofauna standing stock (down to $5 \mathrm{~cm}$ sediment depth) was correlated with carbon concentrations and diffusive oxygen uptake rates, implying that meiofauna standing stocks are linked to food availability and microbial activity. Meiofauna standing stock along the trench axis was markedly higher than the abyssal plain site. Comparing data from the Atacama trench to that of other hadal trench systems confirmed the elevated standing stocks at the trench axis compared to the adjacent abyssal plains. The regional variations between trench systems in standing stocks are correlated to the variations in surface productivity. This study supports the hypothesis that the relatively steep bathymetry of hadal trenches focuses organic material along trench axes and thereby sustains elevated infauna abundance relative to adjacent abyssal plains. 